\title{
Assertiveness Training melalui Bermain Peran dalam Bimbingan Kelompok untuk Meningkatkan Komunikasi Interpersonal Kristinus Sembiring
}

KORESPONDEN PENULIS:

Kristinus Sembiring Universitas Katolik Widya Mandira Kupang

Jalan Jendral Achmad Yani Nomor 50-52, Kupang, Nusa Tenggara Timur, Indonesia

Email: sembiring-kris@yahoo.com

Halaman

$124-128$

\begin{abstract}
This study aimed to find out the improvement of students' interpersonal communication skill after coming to assertiveness training through role play method in group guidance. This was a quasi-experimental study with nonequivalent control group design. The number of subjects in this study was ten people in the experimental group and ten people in the control group. The subject of this study was taken by using purposive sampling technique. The data collection instrument for this study was valid and reliable interpersonal communication scale. The data analysis technique in this study was the nonparametric statistic with Mann Whitney $U$ Test or Wilcoxon Rank Sum Test. The result of the data analysis showed that there was a significant difference between the score of experimental and group control. It means that assertive training through role play in group guidance was more effective to improve students' interpersonal communication skill than the implementation of group guidance without assertiveness training. The result of this study showed that the use of assertiveness training through role play was an effective method in group guidance service for improving students' interpersonal communication. The school counselor can utilize the result of this study to improve the students' interpersonal communication by using assertiveness training strategy through role play in group guidance service.
\end{abstract}

Keywords: assertiveness training, role play, group guidance, interpersonal communication skill

\section{ABSTRAK}

Tujuan studi adalah untuk mengetahui peningkatan kemampuan komunikasi interpersonal siswa setelah mengikuti assertiveness training melalui metode bermain peran dalam bimbingan kelompok. Studi menggunakan jenis penelitian quasi experiment dengan nonequivalent control group design. Jumlah subjek dalam studi ini sebanyak sepuluh orang dalam kelompok eksperimen dan sepuluh orang dalam kelompok kontrol. Penentuan 
subjek dalam studi ini menggunakan teknik purposive sampling. Instrumen pengumpul data menggunakan skala komunikasi interpersonal yang telah diuji validitas dan reliabilitasnya. Teknik analisis data yang digunakan adalah statistic nonparametric dengan uji Mann Whitney U Test atau Wilcoxon Rank Sum Test. Hasil analisis data menyatakan bahwa terdapat perbedaan yang signifikan skor antara kelompok eksperimen dan kontrol, artinya penerapan assertiveness training melalui metode bermain peran dalam bimbingan kelompok lebih efektif meningkatkan kemampuan komunikasi interpersonal siswa dari pada penerapan bimbingan kelompok tanpa assertiveness training. Hasil studi menunjukkan bahwa penggunaan assertiveness training melalui metode bermain peran efektif digunakan sebagai metode dalam layanan bimbingan kelompok untuk meningkatkan kemampuan komunikasi interpersonal siswa. Hasil studi dapat digunakan guru BK di sekolah dalam meningkatkan komunikasi interpersonal siswa menggunakan strategi assetiveness training melalui bermain peran dalam layanan bimbingan kelompok.

Kata kunci: assertiveness training, bermain peran, bimbingan kelompok, keterampilan komunikasi interpersonal

\section{PENDAHULUAN}

Komunikasi merupakan sarana dalam menjalin hubungan interpersonal. Komunikasi interpersonal merupakan sarana penting bagi siswa untuk mengungkapkan pesan yang diinginkan, dirasakan, serta yang dipikirkan sehingga kemudian dapat mempengaruhi proses pembinaan hubungan dengan orang lain. Suciati (2015) menyatakan bahwa komunikasi interpersonal sangat penting bagi manusia khususnya bagi siswa untuk mengungkapkan ideide atau gagasannya ketika proses pembelajaran berlangsung di dalam kelas.

Fenomena rendahnya keterampilan komunikasi telah terjadi di kalangan remaja. Berdasarkan hasil wawancara mendalam (deep interview) terhadap dua guru bimbingan dan konseling dan dua guru matapelajaran pada tanggal 10 September 2015 ditemukan data bahwa masih terdapat siswa SMA Katolik Xaverius Padang yang memiliki permasalahan dalam hal keterampilan komunikasi interpersonal. Sebagai contoh, ketika siswa terlibat komunikasi dengan orang lain, siswa kurang bersikap terbuka dan cenderung kurang memperhatikan teman bicara. Selain itu, ada beberapa siswa yang merasa malu ketika perform di depan siswa-siswa lain dalam satu kelas. Fakta empiris lain sering ditemukan siswa yang kurang mampu menjalin kerjasama saat kegiatan kelompok, kurang mampu menyampaikan isi perasaanya ketika berkomunikasi, cenderung berteriak dan membentak sambil melihat dengan mata tajam sebagai ungkapan kemarahannya ketika diminta oleh temantemannya untuk memberikan pendapatnya, sulit mengawali dan mengakhiri pembicaraan dengan orang yang lebih tua, ragu-ragu untuk bertanya dan menyatakan pendapatnya di dalam kelas, dan sering salah paham dengan teman sebaya.

Sikap asertif dalam berkomunikasi perlu ditingkatkan karena hal tersebut yang dapat menunjang kualitas hubungan interpersonal (Animasahun \& Oladeni, 2012). Asertivitas dalam komunikasi interpersonal dapat ditingkatkan melalui proses latihan yang dirancang melalui dinamika bermain peran dalam bimbingan kelompok untuk membimbing siswa menyatakan pikiran, perasaan, dan bertindak pada asumsi bahwa mereka memiliki hak untuk menjadi dirinya sendiri dan mengekspresikan perasaannya secara bebas dan benar (Repon, 2014). Metode bermain peran dikategorikan sebagai pendekatan belajar yang menjadi satu rumpun dengan metode perilaku yang diterapkan dalam kegiatan pengembangan untuk membantu siswa mengungkapkan perasaan, sikap, tingkah laku dan nilai-nilai kehidupannya.

Studi ini bertujuan untuk mengetahui keefektifan assertiveness training melalui metode bermain peran dalam bimbingan kelompok untuk meningkatkan kemampuan komunikasi interpersonal siswa. Hasil studi dapat dijadikan sebagai strategi bagi guru BK di sekolah dalam meningkatkan komunikasi interpersonal siswa dengan menggunakan assetiveness training melalui bermain peran dalam layanan bimbingan kelompok.

\section{METODE PENELITIAN}

Studi menggunakan pendekatan kuantitatif dengan jenis quasi eksperimen, dan desain nonequivalent control group. Jumlah subjek dalam studi ini sebanyak sepuluh orang dalam kelompok eksperimen dan sepuluh orang dalam 
kelompok kontrol. Penentuan subjek dalam studi ini menggunakan teknik purposive sampling. Instrumen pengumpul data menggunakan skala komunikasi interpersonal yang telah diuji validitas dan reliabilitasnya. Teknik analisis data yang digunakan adalah statistic nonparametric dengan uji Mann Whitney $U$ Test.

\section{HASIL DAN PEMBAHASAN}

Hasil pengolahan data pretest melalui instrumen keterampilan komunikasi interpersonal menunjukkan bahwa kondisi keterampilan komunikasi interpesonal siswa SMA Katolik Xaverius Padang berada pada kategori rendah dan sangat rendah. Potret keterampilan komunikasi interpersonal tersebut sangat memprihatinkan mengingat komunikasi merupakan pondasi dari hubungan interpersonal. Keterampilan berkomunikasi, dalam hal ini komunikasi interpersonal, merupakan kemampuan yang paling dasar, maka orang sering beranggapan bahwa keterampilan berkomunikasi merupakan keterampilan yang akan dimiliki dengan sendirinya oleh seorang individu seiring dengan pertumbuhan fisik dan perkembangan mental manusia yang bersangkutan (Simahate, 2013). Namun, jika keterampilan komunikasi interpersonal tersebut tidak dapat mencapai tataran optimal, maka perlu dikembangkan sehingga dapat meningkatkan kualitas hubungan interpersonal.

Tabel 1

Hasil Analisis Mann-Whitney U 2 Independent Samples Posttest Variabel Kemampuan Komunikasi Interpersonal Siswa Kelompok Eksperimen dan Kelompok Kontrol

\begin{tabular}{lc}
\hline Test Statistics a & Nilai \\
\hline Mann -Whitney U & 2,000 \\
Wilcoxon W & 57,000 \\
Z & $-3,634$ \\
Asymp. Sig. $(2-$ tailed $)$ & 0,000 \\
Exact Sig. $\left[2^{*}(1-\right.$ tailed Sig. $\left.)\right]$ & $0,000^{\mathrm{b}}$ \\
\hline
\end{tabular}

Hasil studi membuktikan bahwa terdapat perbedaan yang signifikan antara kelompok eksperimen dan kelompok kontrol. Hal itu dapat diartikan bahwa penerapan assertiveness training melalui metode bermain peran dalam bimbingan kelompok lebih efektif meningkatkan kemampuan komunikasi interpersonal siswa daripada penerapan bimbingan kelompok tanpa assertiveness training melalui metode bermain peran. Hasil studi tersebut dibuktikan berdasarkan hasil analisis statistik dengan rumus Mann Whitney seperti yang disajikan pada Tabel 1 .

Hasil uji analisis Mann-Whitney diperoleh nilai signifikansi Asymp. Sig. (2-tailed) sebesar 0,000 yang lebih kecil dari $0,05(0,000<0.05)$. Berdasarkan nilai tersebut dapat diartikan bahwa ada perbedaan skor komunikasi interpersonal antara kelompok eksperimen dan kelompok kontrol. Oleh karena itu, penerapan assertiveness training melalui metode bermain peran dalam bimbingan kelompok pada kelompok eksperimen terbukti efektif untuk meningkatkan keterampilan komunikasi interpersonal siswa. Assertiveness training melalui metode bermain peran dalam bimbingan kelompok dapat membantu siswa untuk merefleksikan situasi-situasi yang terdapat dalam kehidupan dan mampu mengembangkan potensi yang dimiliki secara optimal sehingga menjadi individu yang mandiri, dapat menyesuaikan diri dengan lingkungan, dan mampu mengorganisasikan dirinya sendiri saat ini dan di masa yang akan datang.

Menurut Nursalim (2013) bermain peran merupakan salah satu teknik dalam bimbingan kelompok. Bimbingan kelompok memiliki tujuan ganda yaitu untuk mempelajari siswa sebagai individu sekaligus mengenal bagaimana interaksi mereka dengan orang lain, serta membantu siswa untuk mampu menghadapi masalah mereka dan pada akhirnya mampu menyesuaikan diri (Bennet dalam Widyastuti, 2017). Bimbingan kelompok pendekatan assertiveness training melalui bermain peran merupakan suatu kegiatan yang berusaha untuk memberi bantuan kepada individu yang membutuhkannya melalui pemanfaatan semua tanggapan, berbagai reaksi dari anggota kelompok, suasana kelompok sebagai informasi pengetahuan untuk pengembangan diriya, dan anggota kelompok yang terlibat didalamnya (Nurhidayati, 2016). Oleh karena itu, assertiveness training melalui metode bermain peran dalam bimbingan kelompok, tepat sebagai strategi untuk meningkatkan komunikasi interpersonal.

Hasil studi didukung oleh studi yang dilakukan Keliat, Tololiu, Daulima, dan Erawati (2015) yang menyatakan bahwa pelatihan asertif sebagai intervensi kelompok dapat membangun kesadaran diri, menciptakan hubungan baik, meningkatkan komunikasi interpersonal, melatih kemampuan memecahkan masalah, melatih metode 
resolusi konflik, dan membangun ketegasan. Siswa yang telah mengikuti pelatihan ketegasan yang diprogramkan, dapat berhasil dalam komunikasi sosial dengan menggunakan pelatihan perilaku asertif (Kashani \& Bayat, 2010). Keberhasilan ini menyebabkan evaluasi positif terhadap seseorang dan memiliki efek positif pada harga diri. Hasil studi lain menyatakan bahwa assertiveness training mempunyai efek signifikan untuk meningkatkan self esteem pada siswa (Anyamene, Chinyelu, \& Nneka, 2016; Emmanuel, Okreke, \& Anayochi N., 2015; Agbakwuru \& Stella, 2012). Beberapa hasil studi yang telah dipaparkan dapat dijadikan sebagai data pendukung keberhasilan assertiveness training melalui metode bermain peran dalam bimbingan kelompok untuk meningkatkan kemampuan komunikasi interpersonal siswa

Komunikasi interpersonal akan berjalan dengan lancar apabila siswa sebagai pelaku komunikasi interpersonal memiliki sikap asertif di dalam dirinya (Gumilang, 2015). Sikap asertif dapat dipahami sebagai suatu sikap berani dalam mengungkapkan hak-hak pribadi, mengekspresikan pikiran dan perasaan, serta keyakinan siswa secara langsung dan tepat sasaran serta tidak melanggar hak-hak orang lain (Powell \& Newgent, 2011). Senada dengan hal tersebut, Lange (dalam Nursalim, 2013) menyatakan bahwa sikap asertif merupakan suatu sikap berani dalam mengungkapkan hak-hak pribadi, mengekspresikan pikiran dan perasaan serta keyakinan individu secara langsung dan tepat sasaran serta tidak melanggar hak-hak orang lain. Okoli (dalam Makinde \& Akinteye, 2014) menyatakan bahwa asertif merupakan bentuk komunikasi dimana kebutuhan atau keinginan dinyatakan secara jelas dengan menghormati orang lain sebuah interaksi. Oleh sebab itu, asertivitas perlu dimiliki setiap individu agar dapat menyampaikan pikiran dan perasaannya secara jelas kepada orang lain

Assertiveness atau ketegasan memungkinkan seseorang bertindak sesuai kepentingan terbaik mereka sendiri untuk membela diri tanpa mendapat kecemasan untuk mengekspresikan hak pribadi dan tanpa menyangkal hak orang lain (Nelaval, Deepika, \& Babu, 2015). Setelah mengikuti assertiveness training, perilaku keterbukaan diri siswa dalam melakukan komunikasi interpersonal semakin meningkat (Samantaray, Mohapatra, \& Singh, 2016). Hal ini dapat dilihat dari perilaku siswa yang bertindak sesuai dengan keinginannya sendiri yang meliputi kemampuan untuk membuat keputusan, mengambil inisiatif, percaya kepada yang dikemukan sendiri, dapat menentukan suatu tujuan serta berusaha mencapainya, dan mampu berpartisipasi dalam pergaulan. Terkait dengan perasaan, siswa menjadi mampu mengekspresikan perasaan jujur dan nyaman. Sehubungan dengan sikap dan tindakan, siswa memiliki kemampuan untuk menyatakan rasa tidak setuju, rasa marah, menunjukkan afeksi dan persahabatan terhadap orang lain, mengakui perasaan takut atau cemas, serta mampu mempertahankan diri. Selain itu, dalam hubungan dengan tanggung jawab, siswa memiliki kemampuan untuk berkata "tidak" apabila diperlukan, mampu menanggapi kritik dan celaan dengan sikap positif, mampu mengekspresikan dan mempertahan pendapat, tidak mengabaikan hak-hak orang lain, mampu menyatakan kritik secara adil tanpa mengancam, memanipulasi dan mengintimidasi, mengendalikan dan tetap memperhatikan nilai-nilai dan norma yang berlaku sehingga tidak melukai perasaan orang lain.

Hasil penelitian ini menyatakan bahwa tingkat kemampuan komunikasi interpersonal siswa untuk berbicara di depan kelas, keberanian untuk memulai dan mengakhiri pembicaraan dengan orang lain meningkat setelah mengikuti assertiveness training melalui metode bermain peran dalam layanan bimbingan kelompok.

\section{SIMPULAN}

Berdasarkan hasil studi yang telah dipaparkan, maka dapat disimpulkan bahwa penerapan assertiveness training melalui metode bermain peran dalam bimbingan kelompok efektif meningkatkan keterampilan komunikasi interpersonal pada siswa SMA Katolik Xaverius Padang. Hasil studi dapat dijadikan sebagai strategi bagi guru BK di sekolah dalam meningkatkan komunikasi interpersonal siswa dengan menggunakan assetiveness training melalui bermain peran dalam layanan bimbingan kelompok.

\section{REFERENS}

Agbakwuru, C., Stella, U. (2012). Effect of Assertiveness Training on Resilience Among Early-Adolescents. European Scientific Journal, 8(10).

Animasahun, R. A. And Oladeni, O. O., (2012). Effects of Assertiveness Training and Marital Com- 
munication Skills In Enhancing Marital Satisfaction among Baptist Couples in Lagos State, Nigeria. Global Journal of Human Social Science Arts $\mathcal{E}$ Humanities, 12 (14).

Anyamene, A., Chinyelu, N., and Nneka, E. (2016). Effects of Assertive Training on the Low Self-Esteem of Secondary School Students in Anambra State. Journal of Psychology and Behavioral Science, 4(1), 65-78.

Emmanuel, O. O., Okreke, C., and Anayochi N., N. (2015). Assertiveness Training and Cognitive Restructuring Technique on Self-Esteem of Female Undergraduate Victims of Relationship Violence In South-West Nigeria. European Journal of Educational and Development Psychology, 3(2), 15-29.

Gumilang, Galang Surya. (2015). Evaluasi Keterampilan Komunikasi Interpersonal antara Konselor dengan Siswa, Staf Sekolah, dan Orangtua di SMKN Kota Malang. PSIKOPEDAGOGIA Jurnal Bimbingan dan Konseling, 4 (1), 83-87.

Kashani, P. A., and Bayat, M. (2010). The Effect of Social Skills Training (Assertiveness) on Assertiveness and Self-Esteem Increase of 9 to 11 Year-old Female Students in Tehran, Iran. World Applied Sciences Journal, 9 (9).

Keliat, B. A., Tololiu, T. A., Daulima, N. H. C., \& Erawati, E. (2015). Effectiveness Assertive Training of Bullying Prevention among Adolescents in West Java Indonesia. International Journal of Nursing, 2 (1), 128-134.

Makinde, B. O. and Akinteye, A. J. (2014). Effects of Mentoring and Assertiveness Training on Adolescents' Self-Esteem in Lagos State Secondary Schools. International Journal of Social Science Studies, 2(3).

Nelaval, A. D., Deepika, G., and Babu, M. (2015). Research Article a Study to Assess the Assertivess Among Second Year Bsc Nursing Students in Narayana Nursing Institution, Nellore. International Journal of Recent Scientific Research, 6(7), 5542-5544.

Nurhidayati, Diana Dwi. (2016). Peningkatan Pemahaman Manajemen Waktu melalui Bimbingan Kelompok dengan Teknik Problem Solving pada Siswa. PSIKOPEDAGOGIA Jurnal Bimbingan dan Konseling, 5(1). 23-24.

Nursalim, Mochamad. (2015). Pengembangan Profesi
Bimbingan dan Konseling. Jakarta: Erlangga.

Powell, M. L. and Newgent, R. A. (2011). Assertiveness and Mental Health Professionals: Differences between Insight-Oriented and Action-Oriented Clinicians. Journal of The Professional Counselor: Research and Practice, 1(2), 92-98.

Repon, Sarleni. (2014). Upaya Meningkatkan Motivasi Belajar Bahasa Inggris Melalui Media Brosur Bimbingan Belajar dan Diskusi Kelompok pada Siswa SMP. PSIKOPEDAGOGIA Jurnal Bimbingan dan Konseling, 3(1), 29-37.

Samantaray, N. N., Singh, P., Mohapatra, J., and Singh, A. R. (2016). Application of Psychodrama on Conflict Management and Assertive Training. The International Journal of Indian Psychology, 3 (8).

Simahate, Tessa. (2013). Penerapan Komunikasi Interpersonal dalam Melayani Pengguna Perpustakaan. Jurnal Iqra', (7)2.

Suciati. (2015). Komunikasi Interpersonal Sebuah Tinjauan Psikologis dan Perspektif Islam. Yogyakarta: Buku Litera.

Widyastuti, D.A. (2017). Evaluasi Layanan Bimbingan Kelompok di Sekolah Menengah Pertama Berdasarkan Model Kesenjangan (Discrepancy Model). Jurnal Gusjigang, 3(1). 